In the last six chapters he reviews the probable changes in the habitat and status of raptors over the last 3000 years: foods, breeding habits, the problems they have to cope with - often the result of some beastliness by man-and finally conservation. He points out that only in the so-called developed countries does the dislike of raptors degenerate into a systematic campaign of eradication, 'and nowhere do the narrow sectional interests arrogate to themselves to break the law more than in Britain'. Furthermore, the reports of this type of law-breaking more often than not involve gamekeepers employed by some 'very eminent persons indeed'. He emphasises the need for better law enforcement and for public observation hides at the most commonly robbed eagle and kite nests. Finally there are two invaluable appendices, summarising the mass of information on food and what is known about breeding biology.

Apart from a few minor contradictions, this is an excellent and valuable book, with 40 black and white photographs and a number of explicit line drawings by Heinzel.

PETER CONDER

Monkeys without Tails, by John Napier. BBC, $£ 5.25$.

This expanded and updated version of the author's Royal Institution Lectures for young people, televised by the BBC in $1970 / 71$, is a lively and interesting account of the basic principles of evolution with special emphasis on two of the tail-less 'monkeys', the chimpanzee and man.

Professor Napier sets the scene by taking the reader on an imaginary tour of a Primate Zoo, from which we learn that there are 186 different species and about 523 subspecies or races. This is followed by a chapter on evolutionary principles such as variation and natural selection. Illustrating natural selection in action in a behavioural context, there is an interesting account of the potato-washing and wheat-washing activities of the Japanese macaque monkeys of Koshima, which will surely please those who believe that evolution proceeds through females and not males, for in these monkeys the new habits were introduced by a juvenile female and spread to its mother and other females in the group; the adult males do not take any part and 'appear to form a conservative cadre sitting on the sidelines bristling with disapproval at the permissiveness of the females and the younger generation.'

Perhaps the most valuable part of the book is the section on the evolution of the mammals and the emergence of the primates-surprisingly early, although they then showed none of the arboreal characters by which we recognise the order today. In discussing the differences between the gorilla and present-day chimpanzees Professor Napier follows the Dutch zoologist Adriaan Kortlandt in believing that the chimpanzee's aggressive behaviour when faced with predators like leopards, their use of natural objects as tools and their two-footed walk are possibly the result of living in the past in more open savanna country, until the coming of early man, with his clubs and spears, forced them into the forest where they are now found.

The book is well illustrated in colour and black-and-white, and the authoritative text is leavened with wit.

JOHN CLEGG

\title{
Jungle Journeys in Ceylon, by Iris Darnton. Galaxy Books, Lavenham, Suffolk, $£ 4.80$.
}

When I first went out to Ceylon, the people of the hinterland were some of the most delightful one could hope to meet, living at a speed which must have changed little since Biblical times, their villages set in idyllic surroundings amidst the forests and hills. Iris Darnton describes these lovely places, especially the village tanks around which the life of the village is centred, although she does not give any intimate description of the people's daily lives and beliefs; but the language problem makes it difficult to break down their natural shyness. Tropical jungles are profound places, 


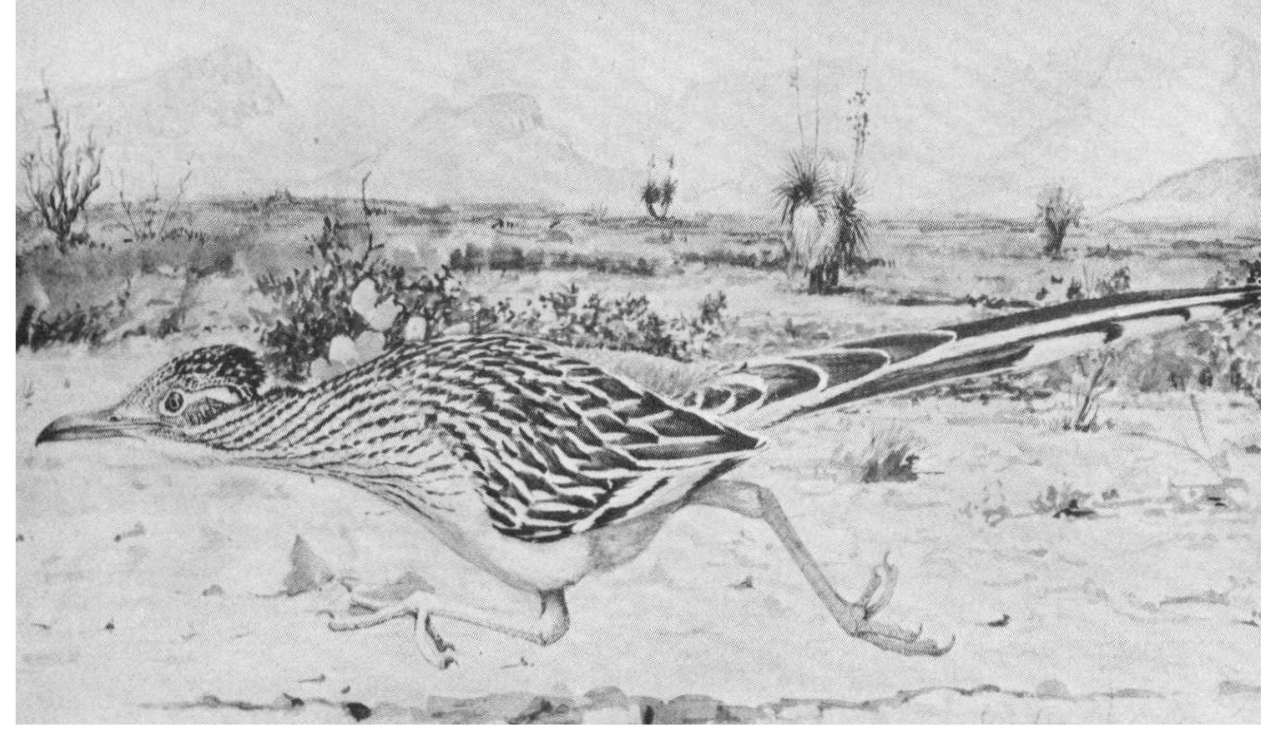

ROADRUNNER, from a painting by Louis Agassiz Fuertes in American Wildlife Painting by Martina R. Norelli, Phaidon, $£ 13.50$, a coffee-table book of beautifully reproduced paintings by Audubon, Catesby, Fuertes, Heade, Thayer and Wilson

whether they be leech-infested rain forests or the arid thorn bush of the dry zone. As she says, 'Ceylon has not only beauty but character-and a soul'. It is in the solitude of the jungle that the feeling of this character and soul will eventually reveal itself as one comes, through time, to appreciate the beliefs and superstitions of these people who live so near to nature.

Iris Darnton describes the buried cities and other ancient and famous ruins, steeped with history, which inspire deep feelings of awe and reverence. But the main object behind this extensive exploration trip was to get to know the birds, many of which are mentioned although none are intimately described. But I envy Iris Darnton her fairy blue bird. In 34 years of extensive birding throughout Ceylon two species avoided me: the Ceylon arrenga and that straggler from South India, the fairy blue bird; she was extremely lucky to see the only one recorded this century.

Today, of course, you cannot expect to find the same jungle and the primitive rest houses described in this account of a journey made in 1947. 'Slum agriculture' having become the order of the day, forests have fallen before the onslaught of the axe and fire, completely changing the environment to the detriment of the endemic fauna and flora.

This is a personal journal of wanderings around the island, describing the places visited, sometimes with rather painful memories of indifferent resthouses and their beds.

The book is liberally illustrated with beautiful black and white photographs, some of which, due to indifferent reproduction, have not been given full justice, and chapter headings are jauntily adorned with the author's pen and ink sketches.

C. E. NORRIS

The Nile, Biology of an Ancient River, edited by Julian Rzoska. Junk, The Hague, 120 Dutch guilders.

This completes a trilogy of recent books which provide a scientific base for the conservation of tropical inland waters, especially those of Africa. The two others, Leonard Beadle's Inland Waters of Tropical Africa, and Rosemary Lowe-McConnell's Fish Communities in Tropical Waters, were noticed in Oryx of February 1976. Julian Rzoska, who is not only editor but also author of a good part of The Nile, was a professor in Poland before the war. After campaigns in Europe he joined Charles Elton in research and control of rodents, and after the war built up a school 